\title{
Intervention of Climate Smart Technologies for Improving Water Productivity in an Enormous Water Use Rice-Wheat System of South-Asia
}

\author{
Akbar HOSSAIN ${ }^{1, a^{*}}$, Rajan BHATT ${ }^{2, b^{*}}$ \\ ${ }^{1}$ Bangladesh Wheat and Maize Research Institute, Dinajpur-5200, Bangladesh \\ ${ }^{2}$ Regional Research Station, Kapurthala, Punjab Agricultural University, Ludhiana, Punjab, India \\ atanjimar2003@yahoo.com; brajansoils@pau.edu
}

\begin{abstract}
Keywords: Rice-Wheat Systems, Smart Agriculture, Sustainable crop production, South-Asia, Water Productivity
\end{abstract}

\begin{abstract}
Intensively practices rice-wheat (R-W) cropping system (RWCS) in South-Asia is suffering from many sustainability issues such as micronutrient deficiencies, labour scarcity, production cost, declining land, declining groundwater level and water productivity along with declining soil health. Climate change further complexes the things in one or other way. Therefore, the intervention of climate smart technologies is urgent for improving water productivity in an enormous water use RWCS of South-Asia. Although, farmers are confused regarding picking of suitable climate smart technology (CST) viz., laser land leveling, un-puddled direct-seeded rice (UPDSR), soil matric potential based irrigation, double zero tillage in wheat followed by rice, raised bed planting, short duration cultivars and correct transplantation time, for enhancing their livelihoods through increasing land and water productivity on one side and mitigating global warming consequences on other. Performance of these technologies is both site and situation specific, and care must be taken in practicing them. Most of them cutting down the drainage losses, which further reduces recharging of soil profile which is not required in water stressed regions while these might be termed as energy-saving technologies; otherwise used to withdraw water from the deeper soil depths. These CST are also useful for waterlogged regions. However, CST viz. correct transplantation time and short duration cultivars partition higher fraction of ET water (evapotranspiration) from $\mathrm{E}$ (evaporation) to $\mathrm{T}$ (transpiration) component which further favour higher grain yields and thus, higher water productivity. Therefore, it is crucial for introduction of CST for improving agricultural and water productivity in the era of climate change in an enormous water use RWCS of South-Asia.
\end{abstract}

\section{Introduction}

Improving Livelihoods through improving productivity of land and water (water productivity is the amount of grains produced per unit of water consumed), is one of the main and important challenge in current decade for the agricultural scientists across the globe for practicing sustainable/climate smart agriculture [1-5] as water resources are shrinking at an alarming rate due to overexploitation of this natural resource. As the durable inter-relations of the events of up-stream and down-stream consumers elucidate, water is a unitary source and should be accomplished consequently [4]. There has been a large expansion of irrigated area at the end of the past century through the manufacturing of the canal network, storing dams and over-manipulation of underground water due to easy access to electricity. In South Asia, major adopted cropping sequences are R-W, rice-rice, rice-other and cotton-wheat (Fig. 1) and the watered area has folded double over the last four decades of the era of twenty. Recently, the underground water manipulation has been accumulating rapidly. Since, surface systems being an important source of groundwater recharge, therefore in many areas, the hydrological link between surface and underground water in the management of water resources has been presumptuous more importance [6]. In South Asia R-W cropping systems, acreage-wise, India stood first followed by Pakistan, Nepal and then Bangladesh (Table 1). 


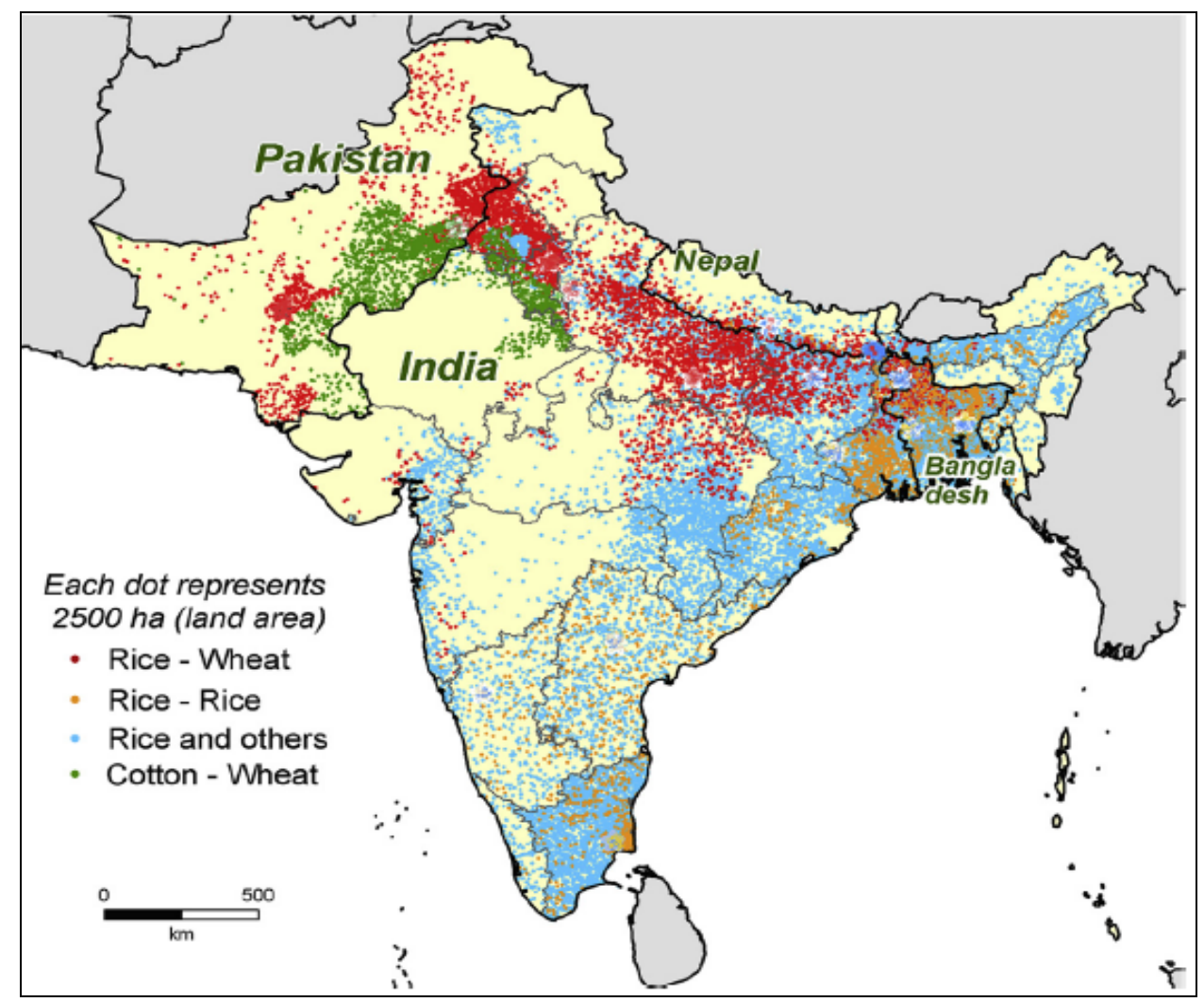

Figure 1. Major cereal -based cropping system in South-Asia. Source: [7].

Table 1. Area under major cropping patterns in South-Asia (Mha). Source: [8].

\begin{tabular}{|l|l|l|l|l|l|}
\hline $\begin{array}{l}\text { Cropping } \\
\text { sequences }\end{array}$ & Nepal & Bangladesh & India & Pakistan & $\begin{array}{l}\text { South } \\
\text { Asia }\end{array}$ \\
\hline Rice- Wheat & 0.57 & 0.40 & 9.20 & 2.20 & 12.37 \\
\hline Maize-Wheat & 0.04 & -- & 1.86 & 1.00 & 2.90 \\
\hline Millet-Wheat & -- & -- & 2.44 & -- & 2.44 \\
\hline Cotton-wheat & -- & -- & 1.09 & 3.10 & 4.19 \\
\hline Fallow-wheat & -- & -- & 2.08 & -- & 2.08 \\
\hline $\begin{array}{l}\text { Sugarcane- } \\
\text { ratoon-wheat }\end{array}$ & -- & -- & 0.97 & -- & 0.97 \\
\hline
\end{tabular}

Enhancing water productivity of irrigation water is an important option where water is scarce compared with land and other resources involved in production Enhancing productivity of per capita of water used (water productivity in crop, livestock and aquaculture production) help to meet the rising demand for food from a growing, wealthier, and increasingly urbanized population. Being the largest consumer of applied irrigation water $\left(230 \mathrm{~km}^{3} \mathrm{yr}^{-1}\right.$, India used up to more than one-fourth of the total global water use [9]. Thus, we will also have to come up with an effective integrated strategy which is both socially and economically adaptable. The underground water uses raised from $10-20 \mathrm{~km} 3$ (the $1950 \mathrm{~s}$ ) to $240-260 \mathrm{~km}^{3}$ up to the end of the previous century [10]. Over a period of 6 years (August 2002-October 2008) with close to normal rainfall, it estimated that the volume of groundwater had declined by $109 \mathrm{~km}^{3}$, double the capacity of India's largest surface reservoir. 
Table 2. Status of water resources (Mha-m) in Punjab, India. Source: [11].

\begin{tabular}{|l|l|}
\hline Water sources & Status \\
\hline Annual canal water available at head works & $14.54 \mathrm{~m}$ ham \\
\hline Annual canal water available at outlet & $1.45 \mathrm{~m} \mathrm{ham}$ \\
\hline Annual ground water available & $1.68 \mathrm{~m} \mathrm{ham}$ \\
\hline Total annual available water resources & $3.13 \mathrm{~m} \mathrm{ham}$ \\
\hline Annual water demand & $4.40 \mathrm{~m} \mathrm{ham}$ \\
\hline Annual water deficit & $1.27 \mathrm{~m} \mathrm{ham}$ \\
\hline
\end{tabular}

At Indian Punjab, farmers are facing a shortage of water supply of around $13 \times 10^{5}$ ha-m of water annually, which withdrawn from the underground (Table 2) and thus as a result water level in central parts of the state declining at an alarming rate for which different Climate smart technologies (CSTs) recommended to improve the waning productivity of irrigation water in the region. However, these CSTs are not universally applicable and their performance in meeting their objective depends upon divergent soil textural class and agro-climatic conditions. In terms of effective use of irrigation water in relation to food grain production, therefore increasing water productivity is the best pointer for making an assessment of different management tools [12] in the area. Although, it is dependent on the performance of differentiated technologies in diverse types of soils, and also their impact must be estimated by directing more and more number of field observations. Further, supplementary food has to harvest from the natural assets. For example, land and water resources are inadequate, thus their per capita accessibility both in terms of quantity and quality deteriorated in the past three decades (Table 3 ).

Generally, people are starved not because of lack of availability but mostly because of accessibility. In worldwide, out of total available water, only about $2.7 \%$ is fresh water, therefore it is an urgent issue for judicious use of water for enhancing water productivity in agriculture as well as other sectors also.

Table 3. Water availability (per capita) in major rice-growing countries in Asia during 1950-2050. Source: [13].

\begin{tabular}{|l|c|c|c|c|c|c|c|c|c|c|}
\hline Country & $\mathbf{1 9 5 0}$ & $\mathbf{1 9 9 5}$ & $\mathbf{2 0 0 0}$ & $\mathbf{2 0 0 5}$ & 2010a & 2015a & 2020a & 2025a & 2050a \\
\hline & \multicolumn{9}{|c|}{$\mathbf{m}^{3}$} \\
\hline China & 5047 & 2295 & 2210 & 2134 & 2068 & 2006 & 1956 & 1927 & 1976 \\
\hline India & 5831 & 2244 & 2000 & 1844 & 1717 & 1611 & 1525 & 1457 & 1292 \\
\hline Japan & 6541 & 4374 & 4314 & 4292 & 4307 & 4348 & 4423 & 4528 & 5381 \\
\hline Indonesia & 31,809 & 12,813 & 12,325 & 11,541 & 10,881 & 10,361 & 9952 & 9609 & 8781 \\
\hline Nepal & 21,623 & 7923 & 6958 & 6245 & 5695 & 5230 & 4820 & 4470 & 3467 \\
\hline Pakistan & 11,844 & 3435 & 3159 & 2822 & 2533 & 2277 & 2069 & 1900 & 1396 \\
\hline Phillipines & 15,390 & 4761 & 4158 & 3778 & 3450 & 3175 & 2945 & 2754 & 2210 \\
\hline Sri Lanka & 5626 & 2410 & 2302 & 2212 & 2117 & 2041 & 1990 & 1961 & 1990 \\
\hline South Korea & 3247 & 1472 & 1424 & 1390 & 1363 & 1345 & 1336 & 1336 & 1500 \\
\hline Thailand & 8946 & 3073 & 2871 & 2714 & 2627 & 2559 & 2505 & 2465 & 2440 \\
\hline
\end{tabular}

a, Projections based on intermediate population growth rate.

The sufficient valuation of advanced CSTs for increasing productivity of water, there should be taken a stock of the costs, welfares and effect on natural assets [1]. The precision laser land leveling, un-puddled direct-seeded rice (UPDSR), soil matric potential based irrigation, double zero tillage in wheat followed by rice, raised bed planting, and correct transplantation time, for enhancing livelihood of farmers through increasing land and water productivity under the changed scenarios of climate for finally improving their livelihoods [5]. Rice with mechanical transplanter, growing of short duration cultivars and mulching are also a common CSTs being recommended in 
the region but their performance for enhancing the productivity of water. Since their enactment is dependent on the site-specific and divergent textural class of soils under multiple agro-climatic regions. Among them, some are drainage cutting technologies while others cause real water savings. Following is the detailed discussion regarding their comparative performance in improving water productivity under variable environmental conditions and thus attempt being made to evaluate the best of them which perform the real water savings and partition higher fraction of the ET water to $\mathrm{T}$ component which further improves livelihoods of the farmers by improving productivity of land and water in the region.

\section{Smart Technologies for Enhancing the Productivity of Applied Water}

\subsection{Transplanting date}

This is the most important technology which treated as smart technology as it partition greater share of the ET water to the transpiration (T) component by reducing the share of E. Earlier farmers in NW India started nursery sowing in April and transplanting in May and this operation required frequent irrigations to have standard yields to meet higher atmospheric water demands which ultimately led to lower water productivity (Table 4), while if farmers followed the recommendation (sowing of nursery/transplanting of paddy seedlings at appropriate time viz., May/June) then during June, monsoon rains are there which increased moisture in air, lesser vapour pressure gradient which decreases wind vapour lifting capacity and E losses and partition higher fraction of ET water to transpiration. Higher the transpiration, higher the nutrient inflows in the plants through roots along-with water which further led to improve the productivity of applied water and cultivated land as well as water productivity of the concerned crop.

Table 4. Transplanting times and rice cultivars effect on yield and water requirements of rice in Punjab (India). Source: [14].

\begin{tabular}{|c|c|c|c|c|}
\hline \multirow[t]{2}{*}{$\begin{array}{c}\text { Transplanting } \\
\text { date }\end{array}$} & $\begin{array}{l}\text { Irrigation water } \\
\text { used }(\mathbf{m m})\end{array}$ & $\begin{array}{l}\text { Grain yield } \\
\qquad\left(\mathrm{t} \mathrm{ha}^{-1}\right)\end{array}$ & $\begin{array}{l}\text { Irrigation } \\
\text { water }(\mathbf{m m})\end{array}$ & Grain yield $\left(\mathrm{t} \mathrm{ha}^{-1}\right)$ \\
\hline & \multicolumn{2}{|l|}{ PR-118 } & \multicolumn{2}{|l|}{ RH-257 } \\
\hline $25^{\text {th }}$ May & 2530 & 7.5 & 2350 & 6.8 \\
\hline $10^{\text {th }}$ June & 2420 & 6.6 & 2310 & 7.3 \\
\hline $25^{\text {th }}$ June & 2270 & 7.1 & 2120 & 7.5 \\
\hline Mean & 2407 & 7.1 & 2260 & 7.2 \\
\hline
\end{tabular}

*PR-118 and RH-257 consumed around 160 and 120 days, respectively

Table 5. Diversification for improving water productivity. Source: [15, 16].

\begin{tabular}{|c|c|c|c|c|c|c|c|}
\hline \multirow[t]{2}{*}{$\begin{array}{l}\text { Cropping } \\
\text { systems }\end{array}$} & \multirow[t]{2}{*}{$\begin{array}{c}\mathbf{E T} \\
(\mathbf{m m})\end{array}$} & \multirow[t]{2}{*}{$\begin{array}{c}\mathbf{E}_{\mathbf{b}} \\
(\mathbf{m m})\end{array}$} & \multicolumn{2}{|c|}{$\begin{array}{l}\text { Component crop } \\
\text { yield }\left(\mathrm{t} \mathrm{ha}^{-1}\right)\end{array}$} & \multirow{2}{*}{$\begin{array}{c}\text { Wheat } \\
\text { equivalent } \\
\text { yield }\left(t^{\left.-h^{-1}\right)}\right.\end{array}$} & \multicolumn{2}{|c|}{$\begin{array}{l}\text { Water productivities } \\
\left(\mathrm{Kg} \mathrm{m}^{-3}\right) \text { based on }\end{array}$} \\
\hline & & & $\mathrm{C}_{1}$ & $\mathbf{C}_{2}$ & & ET & NWL \\
\hline Rice-wheat & 1030 & 210 & 6.0 & 4.5 & 9.7 & 0.94 & 0.78 \\
\hline Cotton-wheat & 980 & 901 & 2.0 & 3.5 & 8.6 & 0.88 & 0.80 \\
\hline Maize-wheat & 860 & 220 & 3.5 & 4.5 & 7.2 & 0.84 & 0.67 \\
\hline
\end{tabular}

Cropping intensity plays a significant role in waning amount of used water. It was demarcated that $[15,16]$ shifting from rice to oilseeds and pulses assisted to enlarge the productivity of applied irrigation water in R-W system in South-Asia. [16] found that ET losses were reduced if R-W crop 
rotation diversified to cotton-wheat or to the maize-wheat rotation; for example, cotton and maize needed lower water requirements than rice cultivation (Table 5).

In wheat, [17] reported that November $10^{\text {th }}$ was the optimum time to ensure higher productivity from water (WP) applied as irrigation and land cultivated under agriculture, however late and earlier sowing decreases the water productivities due to lower yields with higher water used. Thus, up to fifteen November sowing is the best time to get higher water productivity with desirable wheat yield (Fig 2). [14] found that when rice was transplanted on 25 May to 10 June, $110 \mathrm{~mm}$ demand of irrigation water was decreased if transplanting time delayed to $25^{\text {th }}$ of June demand of water was increased as $260 \mathrm{~mm}$, due to increase in ET of late transplanting rice. They also revealed that WP of short duration rice cultivars was higher due to reduce the demand for irrigation water to meet their ET. Similarly, grain yield of cultivar 'RH-257' also increased along with saving of irrigation water that lead to increase the water productivity (Fig. 3). This is also the real water saving technology which improved declining water productivity in the region without cutting drainage losses.

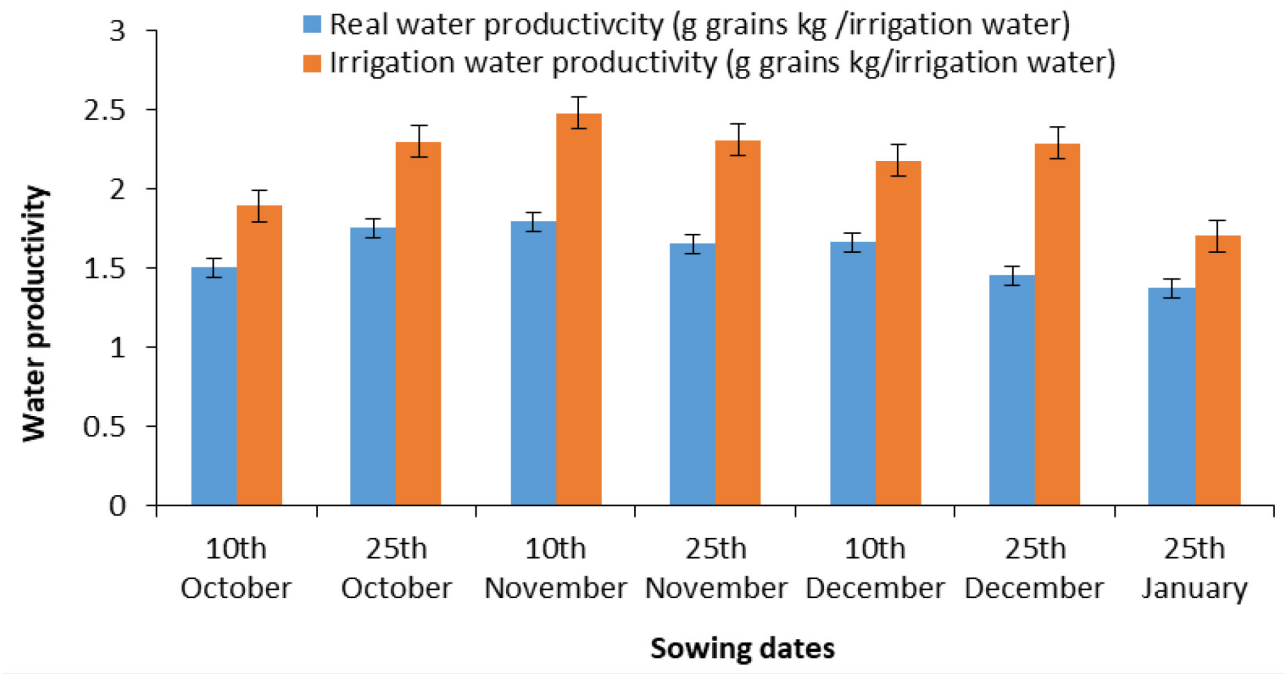

Figure 2. Effect of sowing date on productivity of wheat and irrigation water. Source: [18].

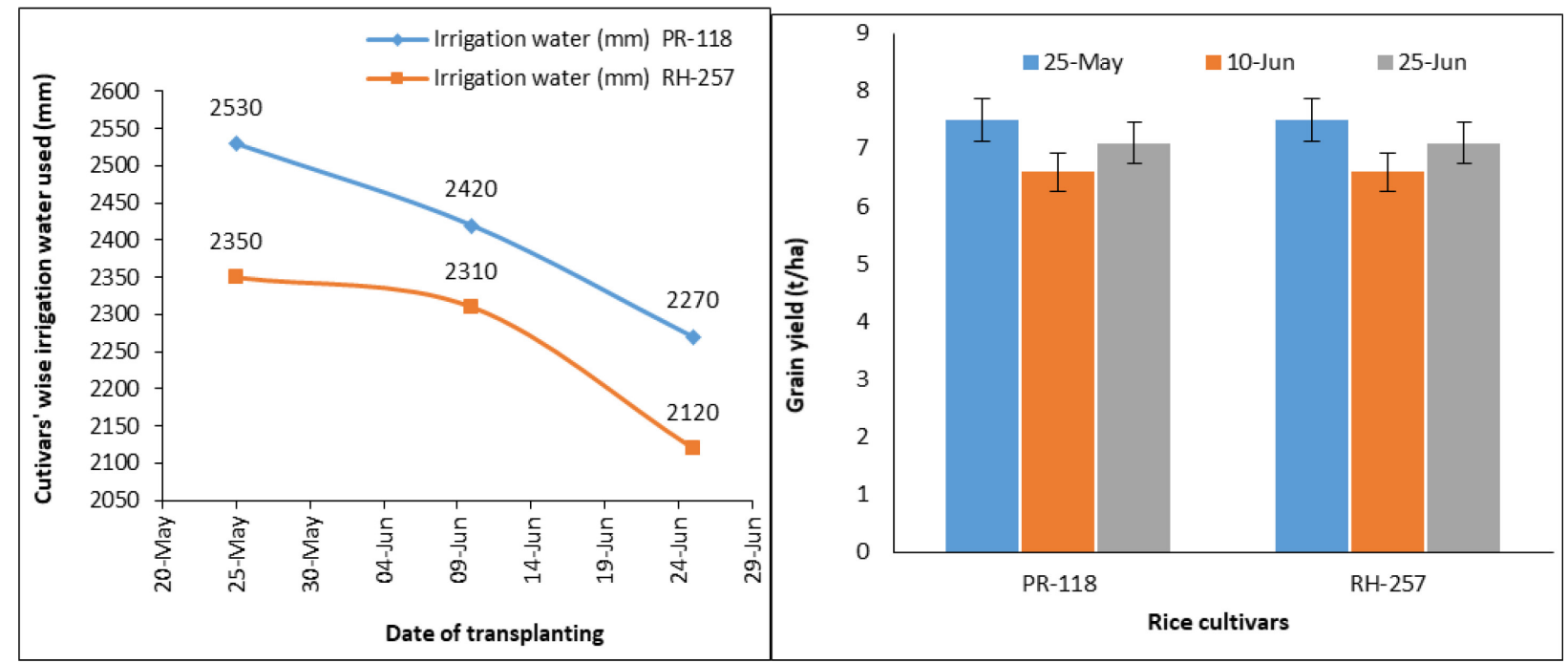

Figure 3. Transplanting dates and cultivar effects on the irrigation water and grain yields Source: [14].

\subsection{Shorter duration cultivars and their impact on water productivity}

Longer the stay of a cultivar onto the field from seed to seed, greater is the evaporative demand and thus higher is both number and quantity of irrigations which needs to be applied for having potential grain yields. However, in the case of shorter cultivars, higher water productivity is 
claimed because of shorter stay of these cultivars on the field. Therefore, it should be recommended short duration crop cultivars led to decreased $\mathrm{E}$ and the total number of irrigations, and thus claimed to be reported with higher water productivity. For example, variety Pusa-44 took 160 days till maturity, consumes significantly higher irrigation water while short duration varieties viz., 'PR-126' and 'PR-127' which took only 123 and 137 days, respectively, had potential to save water by1520\% (Package of Practice, Kharif 2018). Farmers of the region are already suffering from a paucity of water particularly in central Punjab (India), therefore must adopt short and/or medium duration rice cultivars recommended by State Agricultural Universities.

\subsection{Intervening period and soil moisture dynamics in the rice-wheat cropping sequence:}

Till now intervening period is the most neglected area of research, at the time researchers are mostly busy in analyzing the outcome of the climate-smart technologies (CSTs) in the major cropping seasons [19-21] and their residual effect on soil moisture dynamics during the intervening periods mostly ignored [19-22]. [19-21] reported that zero tilled (ZT) wheat evaporates $7.6 \%$ and $12.8 \%$ more, retained $10.3 \%$ and $9.4 \%$ lower volumetric moisture content at $7.5 \mathrm{~cm}$ soil depths and reported to had 28, 18 and $18 \%$ and 21, 16 and $17 \%$ higher soil tension values at 10, 20 and $30 \mathrm{~cm}$ depths of the soil, because of reported higher soil temperature than the conventionally tilled (CTW) wheat plots (2.2\% and $2.1 \%$, respectively) during intervening periods after wheat 2012-13 and wheat 2013-14. However, after rice 2013, ZT plots reported to conserve $4.0 \%$ higher moisture content because of reported $2.3 \%$ lesser soil temperature which evaporates $27.6 \%$ lesser after rice 2013. On average, CTW plots followed by conventionally tilled DSR rice had lower tension values than ZT wheat followed by zero tilled direct seeded rice (ZTW-DSRZT) plots after rice in the year 2013. However, after rice 2014, CTW followed ZTW-DSRZT well-preserved higher soil moisture than ZTW; followed by DSRZT. At $10 \mathrm{~cm}$ of soil surface, soil matric tension (SMT) was found higher in CTWDSRZT (36\%) than CTWDSRP. On an average SMT readings were increased in a faster rate in ZTW plots than its counter plots, due to relatively reduced mulches loaded during the cropping season. In double-ZT system E losses was higher as compared to their other combinations and that might be because of the well joined soil capillaries, earlier conserved higher soil moisture and reported higher soil temperature, more particularly in the surface soils. Thus, there is a need to study the performance of different climate smart technologies (CSTs) in rice-wheat cropping system as a whole including the intervening period in texturally divergent soils under different agroclimatic regions.

\section{Concept and Adaptation Strategies to Reduce the ET in the Rice-Wheat System}

Underground water table alarming decline rate and unscientific conventional practices used to establish the crops in South Asia responsible for the declining both water and land productivity. Adverse effects of the climate change further complicate the situations. ET comprised of E (nonproductive component) and transpiration (productive component) and their effective management in improving both land and water productivity is very crucial. Both soil textural class and varied agroclimatic conditions, effects the water requirements of different crops, therefore the performance of different purposed resource conservation technology varied as per location which further affected the livelihood standards. Our main aim is to reduce the E component and divert the saved moisture to the transpiration as greater the transpiration greater will be the nutrients inflows, which further improves the yields and finally both land and water productivity by one or other mean. Set goals could be achieved only through short duration crop cultivars, timely paddy transplantation, underground pipelines, sprinkler and drip irrigation and zero tillage with mulch at the soil surface.

\subsection{Consequences of ET}

ET is the total consumptive use of irrigation water being used up in the process of $\mathrm{E}$ and transpiration from leaf surface and through stomata. Plants under stressed conditions could modify its stomatal adjustments for modifying transpiration needs to withstand even in the water stressed conditions. During a growing season, leaves of a plant transpire more water many times than its 
own weight. For example, during the growing season, about 11,400-15,100 litres of water per day is transpired by an acre of corn; while about 151,000 litres water per year is transpired by a large oak tree [23]. Our most of interventions stress on enhance the share of the transpiration by diverting the share of E which is an unwanted component of the ET. Further, it is also assumed that the share of total ET remained same in the soil-water balance [24].

\subsection{Adaptation strategies to reduce ET}

Our emphasis through different strategies is to improve the transpiration share in the total share. In this regard, some of the resource conservation technologies viz., short duration rice cultivars, correct transplantation time, mulching through spreading crop residues onto the surface of the soil helps us a lot. By these technologies, we modifies the soil-crop-atmosphere interact conditions in such a way so as to have better water as well as land productivity. Through, short duration rice cultivars viz., 'PR-126' (latest released by Punjab Agricultural University, Ludhiana) claimed to be shortest rice cultivars which decreases the span on soil and also helps a lot to the vegetable growing farmers as fields cleans up much earlier.

Second CSTs such as correct transplantation time might be one of the greatest significant scientific intervention to enhance the WP, which also guide the even politicians to frame up policies. Earlier, farmers used to transplant the paddy nursery in April and transplant in May. During the month of May, the air is quite dry, the vapour pressure gradient is also high, water vapours escape easily from the soil surface, which is easily lift up by high-velocity wind and thus lifts up water vapours to maintain vapour pressure gradient, results in higher E losses. As a result, farmers have to apply frequent irrigations to meet ET water needs, which finally resulted in lower irrigation water productivity while transplanting nursery in the month of June as encountered with rains which moist the air and moist air has lesser E demands, the share of extra E partitioned towards transpiration which further improves the grain yields and livelihoods of the farmers. Punjab government implemented the law to go for nursery sowing after $20^{\text {th }}$ May and transplantation of nursery into the field only after $20^{\text {th }}$ of June from this very year viz., 2018 and the farmers forced to follow this practice by law.

Lastly, by applying crop residues on to the bare soil surface, the following modifications will minimize the $\mathrm{E}$, the unproductive loss of water $[2,4]$.

1. Direct-hitting of the hot-sunrays onto the bare soil surface avoided, thereby modifying the thermal environment of the soil, which further maintains the soil moisture regimes of the soil surface.

2. Reducing the wind velocity, thereby reducing the vapour lifting capacity of the air, thereby minimizing the E losses.

3. Reducing the vapour pressure gradient, thereby hinders the unrestricted diffusion of the water vapours out of the soil into the atmosphere. This further slowdown the rate with which the soil moisture moving up through different capillaries to the surface soils.

It is further very important to delineate that higher the transpiration to higher the diversion of the ET water to transpiration component, will further helps in better inflow of the nutrient along with the water, which further overall improves the livelihoods of the poor farmers of the region by improving land along with water productivity in South Asia.

\section{Summary and Conclusion}

\subsection{Summary}

Finally, the following are some of the points of discussion which arises from the above discussion:

All the climate smart technologies (CSTs) are not real water saving technologies as these are site-specific and their performance varied in texturally divergent soils under different agro-climatic conditions of the South-Asia. 
Among different CSTs viz., laser land leveling, direct seeded rice (DSR), soil matric potential based irrigation, double zero tillage, mechanical transplanting, raised bed planting, short duration cultivars and transplantation time only last two viz. short duration cultivars and transplantation time are recognized as the real water saving technologies as they never cut off drainage losses which responsible for recharge the soil profile and are more suitable for the water stressed regions while other RCTs which cut off the drainage losses are best known as energy-saving technologies are more suitable for the waterlogged regions as they cut off the energy required for pumping extra water.

\subsection{Conclusion}

Among different Climate smart technologies (CSTs) viz., precision leveling of land, tensiometer based irrigations, soil matric potential based irrigation, permanent beds etc. lead to considerable saving in irrigation water quantities by cutting-off the drainage losses, which hinders soil profile recharging and thus, are not desirable in the water stressed areas of South Asia. But, these might claimed as energy saving ones which must be used to withdraw it from the deeper soil depths. These might be beneficial and recommended for the water logged areas of South-Asia, where drainage is not required at all. However, for the water stressed regions of South Asia, CSTs viz., short duration cultivars and correct transplanting time are the most effective ones as they recapture the water used, reduced the share of unproductive E and known as "Real Water Saving Technologies" which partition higher fraction of the ET water to the transpiration. Higher transpiration favour higher inflow of the nutrients in roots, which favour higher grains with lesser irrigations which finally improves the water Productivity in an Enormous Water Use Rice-Wheat System of South-Asia. Further, these CSTs are site and situation specific and their performance varied as per texturally divergent soils and under different agro-climatic conditions. Hence, one should be very careful in adopting and practicing them onto their fields. These CST are also useful for waterlogged regions. Therefore, it is crucial for introduction of CST for improving agricultural and water productivity in the era of climate change in an enormous water use RWCS of South-Asia

\section{Conflict of interest}

We hereby declare that the review does not have any material which has been accepted to publish in any journal and also to the best of our knowledge, the review contains no copy of any material previously published or written, except where due permission and reference is made in the text.

\section{References}

[1] E. Humphreys et al., Halting the groundwater decline in north-west India-which crop technologies will be winners? Advances in Agronomy. 109 (2010) 156-99.

[2] R. Bhatt, K.L. Khera, Effect of tillage and mode of straw mulch application on soil erosion in the submontaneous tract of Punjab, India, Soil and Tillage Research. 88 (2006) 107-115.

[3] R. Bhatt, Soil water dynamics and water productivity of R-W system under different establishment methods, Dissertation submitted to Punjab Agricultural University, Ludhiana, Punjab, India. 2015.

[4] R. Bhatt et al., Sustainability issues on rice-wheat cropping system. International Soil and Water Conservation Research. 4 (2016) 68-83. DOI: 10.1016/j.iswcr.2015.12.001.

[5] R. Bhatt, Soil Water Balance Computation - The Instrumental Part, Annals of Agricultural \& Crop Sciences, USA. 2(1) (2017) 1-6.

[6] R. Bhatt, S.S. Kukal, Tillage and establishment method impacts on land and irrigation water productivity of wheat-rice system in North-west India, Experimental Agriculture. 53(2) (2017) 178-201. DOI: 10.1017/SOO14479716000272. 
[7] IRRI, Revitalizing the Rice Wheat Cropping Systems of the Indo-Gangetic Plains: Adaptation and Adoption of Resource Conserving Technologies in India, Bangladesh, and Nepal. Final Report, (IRRI Ref. No. DPPC2007-100). International Rice Research Institute, (2009).

[8] S.S. Kukal et al., Improving water productivity of wheat-based cropping systems in South Asia for sustained productivity. Advances in Agronomy. 127 (2014) 157- 230.

[9] S.K. Tyagi, P.S. Datta, R. Singh, Need for proper water management for food security, Current Science. 105 (2012) 690-695.

[10] S.S. Prihar, V.K. Arora S.K. Jalota, Enhancing crop water productivity to ameliorate groundwater decline. Current Science. 99 (2010) 588-593.

[11] A.K. Jain, R. Kumar, Water management issues-Punjab, North-West India. Proc paper In: Indo-US Workshop on Innovative E-technologies for Distance Education and Extension/Outreach for Efficient Water Management. ICRISAT, Hyderabad, (2007).

[12] T.P. Tuong, S.I. Bhuiyan, Increasing water-use efficiency in rice production: farm-level perspectives. Agricultural Water Management. 40(1) (1999) 117-122.

[13] T. Gardner-Outlaw, R. Engelman, Sustaining Water, Easing Scarcity: A Second Update. Population Action International, Washington, DC, (1997) 19 pp.

[14] S.K. Jalota et al., Integrating effect of transplanting date, cultivar and irrigation on yield, water saving and water productivity of rice (Oryza sativa L.) in Indian Punjab: Field and simulation study, Agricultural Water Management. 96 (2009) 1096-1104.

[15] V.K. Arora, S.K. Jalota, K.B. Singh, Managing water crisis for sustainable crop productivity in Punjab; an overview, Journal of Research (PAU). 45 (2008) 17-21.

[16] S.K. Jalota, V.K. Arora, Model-based assessment of water balance components under different cropping systems in north-west India, Agricultural Water Management. 57 (2002) 75-87.

[17] J. Timsina et al., Evaluation of options for increasing yield and water productivity of wheat in Punjab, India using the DSSAT-CSM-CERES-Wheat model, Agricultural Water Management. 95(9) (2008) 1099-1110.

[18] J. Timsina, D.J. Connor, Productivity and management of rice-wheat cropping systems, Issues and challenges, Field Crops Research. 69 (2001) 93-132.

[19] R. Bhatt, S.S. Kukal, Delineating soil moisture dynamics as affected by tillage in wheat, rice and establishment methods during intervening period, Journal of Applied and Natural Sciences, 7(1) (2015) 364-368.

[20] R. Bhatt, S.S. Kukal, Soil moisture dynamics during intervening period in rice-wheat sequence as affected by different tillage methods at Ludhiana, Punjab, India, Soil and Environment (Soil Science Society of Pakistan) 34 (2015) 82-88.

[21] R. Bhatt, S.S. Kukal, Soil temperature, evaporation and water tension dynamics at upper vadose zone during intervening period, Trends in Biosciences. 8(3) (2015) 795-800.

[22] R. Bhatt, S.S. Kukal, S. Arora, Resource conservation technologies for improving water productivity, Journal of soil and water conservation 12(4) ((2013) 313-320.

[23] Balwinder-Singh et al., The effect of rice straw mulch on evapotranspiration, transpiration and soil evaporation of irrigated wheat in Punjab, India, Agricultural Water Management. 98 (2011) 1847-1855.

[24] USGS, The Water Cycle: USGS Water Science School. U.S. Department of the Interior and Geological Survey, (2016). Available: https://water.usgs.gov/edu/ watercycleevapotranspiration.html. Accessed 11 December 2018. 